he emphasized that "in building a world where machines do the work which used to be done by men, it is not good enough to build men who can only work like machines. It is not enough to produce managers who know how to increase production; of far greater importance is it to produce managers who know why they should increase production, or even whether they should".

To the recognized "deeply humanizing, deep moral importance of liberal studies", Mr. Rée added the less recognized importance of planned and wisely used leisure. He warned that "To an ever increasing extent we have handed over the organization of our spare time to those who can make money out of us, to the purveyors of entertainment, to those who can offer us diversion without exertion, and hour after hour we are content to watch, to listen and to consume".

He concluded by envisaging the great contribution educational institutions could make by a counter attack on the creeping disease of passive pleasures which is eating away the soul of modern man. "If we could make the effort, all these things (commercial entertainment, ostentatious expenditure, slot machines and cinemascopes) could be swept away and we should look upon automatic factories and computing machines as our benefactors enabling us and our children to taste to the full the real joys of life."

In the discussion which followed, the suggestion was made that we may have to look to women to swell the force of technicians. Sir Ben Lockspeiser disagreed with Dr. Richardson's complacency on numbers; he emphasized that every technical industry, including government departments, is orying out increasingly for more and more technicians. He concluded by warning his audience that automation is not before us as a choice--it is a sheer necessity. Without automation we cannot increase production, without increased production we cannot remain competitive, without trade we shall perish.

J. E. RICHARDSON

\section{THIRD INTERNATIONAL CONGRESS OF BIOCHEMISTRY}

$\mathrm{T}$ HE Third International Congress of Biochemistry was held in Brussels during August 1-6, under the presidency of Prof. E. J. Bigwood, and was attended by more than seventeen hundred delegates from all parts of the world. The official opening on August 1 was followed by the inaugural lecture, given at the Palais des Beaux-Arts by C. Martius, of Würtzburg, his subject being "Thyroxin und oxidative Phosphorylierung". On the evening of the same day the official reception was held at the Musées Royaux d'Art et d'Histoire du Cinquantenaire, and was preceded by a tour of the exhibits.

Besides the opening and closing lectures, formal lectures were given by P. S. Sarma (India) on biochomical aspects of Corcyra nutrition; R. H. S. Thompson (Great Britain) on biochemical disorders in peripheral neuritis; N. M. Sissakian (U.S.S.R.) on biochemical properties of plastids; P. H. Bell and R. G. Shepherd (United States) on purification and structure of $\beta$-corticotrophin and its active degradation products; P. Grabar (France) on the study of mixtures of proteins by electrophoretic and immunoelectrophoretic analysis in gels; and L. Seekles (Holland) on the role of the trace elements in nutri- tion. F. B. Straub (Hungary), who was also due to speak, was unable to attend.

The remainder of the scientific programme was divided into two classes of communications which were concurrent. These were, first, report sessions, which consisted of reviews given by workers in the various fields, and which were followed by prepared discussions by invited speakers who had been provided with advance copies of the talks; and, secondly, the scientific communications proper, which were short papers dealing with recent research.

The reports, most of which were printed and circulated to members of the Congress beforehand in the form of a most useful booklet, covered a wide field ranging from pure chemistry, on one hand, to pure biology on the other. The subjects discussed included the biosynthesis of peptides (H. Borsook), photosynthesis (M. Calvin), transmethylation (G. L. Cantoni), formation of organic acids in moulds (E. B. Chain), growth stimulation by antibiotics (M. E. Coates and S. K. Kon), antibiotic polypeptides (L. C. Craig), proteolytic enzymes (P. Desnuelle and M. Rovery), hexose monophosphate oxidation (F. Dickens), physical chemistry of deoxyribonucleic acid (P. Doty and N. Simmons; C. Sadron), structure of polypeptides and proteins (A. Elliot), genetic function of deoxyribonucleic acid (H. Ephrussi-Taylor; 0 . Maaloe), incorporation of amino-acids in the presence of ribonucleic acid fragments (E. F. Gale), aminoaciduria (H. Harris), effects of ionizing radiation (G. Hevesy and A. Forssberg), antimetabolites related to purines (G. H. Hitchings and G. B. Elion), mucopolysaccharides (R. W. Jeanloz), carbamyl phosphate (M. E. Jones, L. Spector and F. Lipmann), energetic coupling (H. Lardy), uridine coenzymes (L. F. Leloir), metalloflavoproteins (H. R. Mahler), ribonucleic acids (R. Markham), determination of steroids (G. F. Marrian), biochemistry of the nucleus (A. E. Mirsky), brain biochemistry (A. V. Palladine; A. J. Rosenberg), skeletal muscle metabolism (S. V. Perry), antibiotics and intestinal flora (L. Y. Quinn), biochemistry of anæsthesia (J. H. Quastel), aseptic breeding of rats (J. Reyniers), bacterial cell structure (M. R. J. Salton), cell structure and metabolism (W. C. Schneider), porphyrin biosynthesis (D. Shemin), respiratory chain phosphorylation (E. C. Slater), respiratory adaptation ( $\mathrm{P}$. Slonimski), enzymic adaptation (S. Spiegelman), antibiotics and nutrition (E. L. R. Stokstad), hormonal regulatory mechanisms (E. W. Sutherland), ion transport (H. H. Ussing and B. Andersen), nitrogen fixation (A. I. Virtanen), muscle and cell contraction (H. H. Weber) and the chemistry of nerve activity (I. B. Wilson).

The original communications, which numbered more than eight hundred in all, were given in seven. teen sections: organic chemistry of substances of biological interest ; chemistry and physical chemistry of proteins and polypeptides; chemistry and physical chemistry of nucleoproteins and nucleic acids; enzymology ; intermediary metabolism ; cellular oxidation and oxidative phosphorylation; biochemical regulation; cellular biochemistry; biochemistry of muscle and the central nervous system; chemical microbiology ; plant and soil biochemistry ; zoological chemistry ; nutrition; pathological chemistry and immunochemistry; pharmacological chemistry; clinical chemistry; and industrial biochemistry. Such a division into sections is somewhat arbitrary and, consequently, related papers were to be found in several different sections. A gallant and partly successful attempt to overcome this deficiency was made by 
the organizers, who provided the delegates with a timetable for each day and who enforced a most rigid control over the time taken by each speaker. However, on occasion, as many as twenty choices were afforded at any one time, in as many different places, and it is unlikely that anyone managed to attend all the papers which he wished to hear.

An excellent item of organization, and one which can be recommended to organizers of future congresses of this size, was the provision of ample space for informal meetings between delegates, both at the Congress headquarters at the University of Brussels and in the adjacent Cité Universitaire, where all manner of facilities were provided.

In addition to the opening reception a number of social activities were arranged, the main one being a concert given by the Belgian National Orchestra at the Palais des Beaux-Arts. There was no formal Congress banquet, but some informal sectional dinners were given, and the International Association of Clinical Chemistry arranged a banquet open to all members of the Congress. Both the Russian and the Polish delegations gave receptions at their respective embassies, and these wore attended by guests from both sides of the Atlantic. An exhibition of scientific equipment was given at the Congress headquarters, and a number of British scientific equipment manufacturers were represented. The closing lecture was given by $\mathrm{V}$. du Vigneaud (New York) on the isolation and proof of structure of the vasopressins and the synthesis of octapeptide amides with pressor-antidiuretic activity.

The next Congress will be held in Vienna in 1958.

\section{RADIATIVE BALANCE IN THE ATMOSPHERE}

\section{ROYAL SOCIETY DISCUSSION}

$I^{\mathrm{T}}$

$T$ is appropriate, in view of the forthcoming intensification of atmospheric research during the International Geophysical Year of 1957-58, to examine the present state of research in such a subject as radiative balance in the atmosphere, and a one-day discussion meeting on this subject was held in London at the Royal Society on June 9. In such a short period it was clearly out of the question to attempt any comprehensive survey, and attention was concentrated instead on subjects in which research is being actively pursued. Many of those who took part are contributors to the Gassiot Committee programme of research on photochemical equilibrium in the atmosphere. Two invited speakers from abroad, Dr. F. Möller (University of Mainz) and Dr. M. V. Migeotte (Institut d'Astrophysique, Liège), made interesting contributions. The programme was arranged so that the morning and early afternoon were mainly devoted to the lower atmosphere, up to and including the stratosphere, and the late afternoon to the higher levels of the atmosphere.

The discussion was introduced by Prof. H. S. W. Massey (University College, London), who first outlined the general nature of the radiation balance in the atmosphere and indicated the importance of the different absorption, emission and scattering processes which are involved. The second part of his talk was concerned with the temperature and pressure distribution in the atmosphere. These may be directly studied up to altitudes of $150 \mathrm{~km}$. by means of instruments transported by rockets. Methods of measurement of pressure, temperature and density were outlined, and the interrelation of these three quantities was pointed out as a useful check on the results obtained. Special attention was directed by Prof. Massey to the way in which the rocket observa. tions of pressure, taken above White Sands, New Mexico, agree well with results obtained by balloon flights up to altitudes of $24 \mathrm{~km}$. The importance of further rocket measurements in different geographical locations was stressed.

Dr. Möller next discussed the pattern of radiative heating and cooling in the troposphere and lower stratosphere. After describing the distribution of temperature and of the cooling-rate by water vapour in some characteristic atmospheres at different latitudes, he directed attention to systematic differences from this characteristic behaviour which have been observed in the last year. These differences he ascribes to the effect of cloud layers, and the remainder of his contribution was concerned with these effects.

Statistical studies of the frequency and thickness of clouds over Germany during the period 1930-40 are now proceeding at the Meteorologisch-Geophysikalisches Institut at Mainz, these being based on the observations of the Wetterflugstellen. Using these data, radiation fluxes and mean cooling water characteristics of cyclonic warm air have been computed and show that at every height the cooling is slightly increased by the cloud." Further work on these lines is proceeding.

Dr. A. R. Curtis (University of Sheffield) described the elaborate computations which he is carrying out on radiative heating-rates in the atmosphere. The starting-point is the derivation from the equation of radiative transfer of an expression for the rate of heating at any height in a plane-stratified atmosphere due to interaction of molecules of a single absorbing constituent with radiation. Even in this simplified case the expression is quite formidable. Knowledge of line frequencies and intensities and of line shape as a function of height is required. To make the calculations tractable, it is assumed that the line intensities are distributed according to a probability function. Approximate calculations for the $15-\mu$ carbon dioxide band have been made, but further work will be carried out using electronic computation.

Dr. Migeotte described the results of high-resolution spectroscopic investigation of minor atmospheric constituents-ozone, nitrous oxide, methane, monodeuterated water and carbon monoxide. Several bands, as they appeared on solar spectrograms taken at the International Scientific Station on the Jungfraujoch at an altitude of $3,850 \mathrm{~m}$., were shown; they were obtained using the prism-grating infra-red spectrograph of the University of Liège. Attention was directed by Dr. Migeotte to the presence of the $9-\mu$ band of ozone and the $17-\mu$ band of nitrous oxide in the solar spectrum. An atlas of the solar spectrum containing reproductions of the Jungfraujoch records is now ready for publication.

The afternoon session of the meeting began with a discussion by Dr. G. D. Robinson (Kew Observatory) of the scope of observations of solar and terrestrial radiation at the earth's surface. This included a critical survey of recent measurements of quantities important in determining the radiative balance at the latitude of Kew. In addition, Dr. Robinson discussed the contribution that can be made to the solution of the meteorological problem by the programme of measurements proposed for the Inter- 